\title{
ГИДРОХИМИЧЕСКИЙ СТОК РЕЧНЫХ ВОД ЮГА ХАБАРОВСКОГО КРАЯ В ПЕРИОД ЛЕТНЕГО ПАВОДКА
}

\author{
Павлова Галина Юрьевна', \\ pavlova@poi.dvo.ru \\ Вах Елена Александровна2,1, \\ Adasea@mail.ru \\ Тищенко Павел Яковлевич1, \\ tpavel@poi.dvo.ru \\ Петухов Валерий Иванович2, \\ petukhuvv@mail.ru \\ 1 Тихоокеанский океанологический институт им. В.И. Ильичева Дальневосточного отделения \\ Российской академии наук, \\ Россия, 690041, г. Владивосток, ул. Балтийская, 43. \\ 2 Дальневосточный федеральный университет, \\ Россия, 690950, г. Владивосток, ул. Суханова, 8.
}

\begin{abstract}
Актуальность: изучение гидрохимического стока рек как одного из основных индикаторов экологического состояния водных объектов.

Цель: получение новых знаний о гидрохимическом стоке рек юга Хабаровского края, которые необходимы для объективной оценки экологического состояния поверхностных вод края и проведения эфффективных водоохранных мероприятий.

объекты: р. Амур и семь рек бассейна р. Уссури (одного из наиболее значимых притоков Амура): Бикин, Хор, Подхоренок, Бира, Кия, Малая Чирка и 2-ая Седьмая.

Методы. Концентрации макро-анионов (Cl, $\left.\mathrm{SO}_{4}{ }^{2-}\right)$ измерялись методом ионно-обменной хроматографрии; макро-катионов $\left(\mathrm{Na}^{+}, \mathrm{K}^{+}, \mathrm{Ca}^{2+}, \mathrm{Mg}^{2+}\right)$, микроэлементов и редкоземельных элементов - методом ICP-MS (Agilent, 7500c). В качестве концентрации гидрокарбонатного иона $\left(\mathrm{HCO}_{3}^{-}\right)$принималась величина щелочности.

Результаты. В июле 2011 г. проведены комплексные гидрохимические исследования в р. Амур и семи реках бассейна р. Уссури (одного из наиболее значимых притоков Амура): Бикин, Хор, Подхоренок, Бира, Кия, Малая Чирка и 2-ая Седьмая. В пробах речной воды были определены параметры основного солевого состава, микроэлементов и редкоземельных элементов. В период высокого расхода воды в высоко увлажненных южных районах Хабаровского края речные воды очень схожи по типу и величине минерализации: среди катионов доминирует $\mathrm{Ca}^{2+}$, основным противо-анионом является $\mathrm{HCO}_{3}^{-} ;$воды ультрапресные, $\sum$ i не превышает 50 ме/л. В поверхностных водах всех исследованных рек обнаружены высокие концентрации растворенных форм $\mathrm{Al}, \mathrm{Fe}$ u Pb. B p. Малая Чирка - высокие концентрации растворенных Co, Cu, Mn и экстремально высокие Cd, превышающие средние глобальные концентрации в 40 раз. Содержание остальных микроэлементов в исследуемых реках в целом соответствовало их средним глобальным концентрациям и является характеристикой природного регионального фона в период летних паводков. Установлен региональный уровень суммарных концентраций растворимых форм редкоземельных элементов (1,44-5,44 мка/л). Величины концентраций редкоземельных элементов в исследуемых реках указывают на однотипность источника их поступления. Рассчитанные суммарные суточные потоки макро-ионов, микроэлементов и редкоземельных элементов, поставляемые реками Бира, Кия, Подхоренок, Бикин, Хор и Амур, равны 61894, 377 и 2,21 m/cym, coomвеmственно.
\end{abstract}

\section{Ключевые слова:}

Гидрохимический сток, макро-ионы, микроэлементы, редкоземельные элементы, река, Хабаровский край.

\section{Введение}

Гидрохимический сток является важным интеграционным показателем взаимодействия компонентов природной среды и хозяйственной деятельности. Его величина изменяется в широких пределах не только для разных рек [1], но и в пределах бассейна одной реки с разными природными зонами [2]. В настоящее время изменение климата приводит к интенсивной деградации многолетней мерзлоты в северных районах РФ [3]. Этот процесс может изменить систему питания северных рек, увеличив вклад грунтовых и подмерзлотных вод в речной сток. В связи с изменением климата происходят временные изменения гидрохимиче- ского стока [4]. Другим фактором является разносторонняя хозяйственная деятельность (горнохимическое производство, вырубка леса, сельское хозяйство), которая может оказывать влияние на эвтрофность рек, благодаря увеличению концентраций органических веществ, биогенных элементов, что наблюдается, например, при лесных пожарах [5]. Поэтому современное знание химического и экологического статуса слабоизученных речных вод Хабаровского края является актуальной задачей в условиях меняющейся окружающей среды. Новые знания о гидрохимическом стоке рек необходимы для объективной оценки экологического состояния территории края. 
Проблема качества поверхностных вод Хабаровского края неоднократно обсуждалась в литературе [5-7]. По территории края протекает более 120 тыс. рек. Химический состав и сток растворенных веществ большинства рек не изучен. Особую тревогу вызывают малые реки, которые наиболее уязвимы в отношении антропогенного воздействия на их водосборные бассейны. Постоянные наблюдения за качеством воды проводятся Росгидрометом (ФГБУ «Дальневосточное УГМС») на 23 водных объектах: 22 реках и в Амурской протоке. По результатам наблюдений 2014-2016 гг. практически все исследуемые водные объекты загрязнены соединениями марганца, общего железа, меди и цинка $[8,9]$. Пять из восьми рассмотренных в этой работе рек включены в программу мониторинга поверхностных вод края: Амур (г. Хабаровск), Хор (пгт. Хор), Подхоренок (п. Дормидонтовка), Кия (с. Переяславка) и Бира (с. Лермонтовка) $[8,9]$. Постоянные гидрохимические наблюдения в реках Бикин, Малая Чирка и 2-я Седьмая отсутствуют. По комплексу основных загрязняющих веществ одной из самых неблагополучных рек края считается $\mathrm{p}$. Подхоренок. Состояние воды в ней ухудшается из года в год: в 2013 г. она классифицировалась как «загрязненная» (3 класс качества), в 2014 - «грязная» (4 класс), а в 2016 - «экстремально грязная» (5 класс). Смена класса качества воды за несколько последних лет произошла в реках Хор, Кия и Бира - со «слабо загрязненных» (2 класс) на «грязные» (4 класс) $[8,9]$. В реках Подхоренок и Бира отсутствует организованный сброс сточных вод. Наиболее благополучная ситуация складывается с водами р. Амур, качественные характеристики которых в последние годы не изменились - «загрязненная», 3 класс.

Изучение химического состава поверхностных вод Хабаровского края проводилось на протяжении продолжительного периода Институтом водных и экологических проблем ДВО РАН [5-7], а также ТИГ и ТОИ ДВО РАН $[10,11]$. Эти работы отличались, как правило, ограниченным числом анализируемых компонентов (биогенные и основные элементы, реже микроэлементы) и касались в основном реки Амур. Измерения редкоземельных элементов в речных водах края не проводились.

Цель данной работы - получение новых знаний о гидрохимическом стоке рек юга Хабаровского края, которые необходимы для объективной оценки экологического состояния территории края и проведения эффективных водоохранных мероприятий. В работе представлены данные о распределении растворенных форм макро-, микро- и редкоземельных элементов в поверхностных водах 8-ми разнопорядковых рек южной части Хабаровского края.

\section{Материалы и методы исследования}

Для решения поставленных задач на территории Хабаровского края было выбрано 8 водных объектов: p. Амур (главная водная артерия края) и семь рек бассейна p. Уссури (одного из наиболее значимых притоков Амура): Бикин, Хор, Подхоренок, Бира, Кия, Малая Чирка и 2-я Седьмая (рис. 1). Согласно суще- ствующей в стране классификации рек по площади их бассейнов (ГОСТ 19179-73), Бира, Кия, Малая Чирка и 2-я Седьмая относятся к категории малых рек; Бикин, Хор и Подхоренок - средние реки; Амур - большая река.

Гидрохимические исследования в этих реках были проведены 11 июля 2011 г. Пробы воды были отобраны с поверхностного горизонта в точках с координатами: $46,773^{\circ}$ с.ш., $134,278^{\circ}$ в.д. - р. Бикин; $47,141^{\circ}$ с.ш., $134,345^{\circ}$ в.д. - р. Бира; $47,532^{\circ}$ с.ш., $134,795^{\circ}$ в.д. p. 2-я Седьмая; $47,789^{\circ}$ с.ш., $134,928^{\circ}$ в.д. - р. Подхоренок; $47,866^{\circ}$ с.ш., $134,965^{\circ}$ в.д. - р. Хор; $47,960^{\circ}$ с.ш., $135,082^{\circ}$ в.д. - р. Кия; $48,257^{\circ}$ с.ш., $135,053^{\circ}$ в.д. p. Малая Чирка; $48,471^{\circ}$ с.ш., $135,053^{\circ}$ в.д. - р. Амур. Места отбора были приближены к автомобильной трассе М-60 (рис. 1). Образцы воды отфильтровывали через мембранный фильтр 0,45 мкм. Пробы для анализа макро-катионов, микроэлементов и редкоземельных элементов подкислялись азотной кислотой. Концентрации макро-анионов $\left(\mathrm{Cl}^{-}, \mathrm{SO}_{4}{ }^{2-}\right)$ были измерены методом ионно-обменной хроматографии на хроматографе LC-10A Shimadzu (Япония), а макрокатионов $\left(\mathrm{Na}^{+}, \mathrm{K}^{+}, \mathrm{Ca}^{2+}, \mathrm{Mg}^{2+}\right)$, микроэлементов и РЗЭ - масс-спектрометрическим методом с индуктивно связанной плазмой в Аналитическом центре ДВГИ ДВО РАН. В качестве концентрации гидрокарбонатного иона $\left(\mathrm{HCO}_{3}^{-}\right)$принималась величина общей щелочности. Подробное описание методики определения общей щелочности приведено в работе [12]. Общая минерализация речной воды $\left(\sum_{\mathrm{i}}\right)$ определялась как сумма вкладов макрокомпонентов:

$$
\sum_{\mathrm{i}}=\left[\mathrm{Na}^{+}\right]+\left[\mathrm{K}^{+}\right]+\left[\mathrm{Ca}^{2+}\right]+\left[\mathrm{Mg}^{2+}\right]+\left[\mathrm{SO}_{4}{ }^{2-}\right]+\left[\mathrm{Cl}^{-}\right]+\left[\mathrm{HCO}_{3}{ }^{-}\right] .
$$

Здесь в скобках концентрации параметров общего солевого состава (ОСС) в речных водах в размерности мг/л.

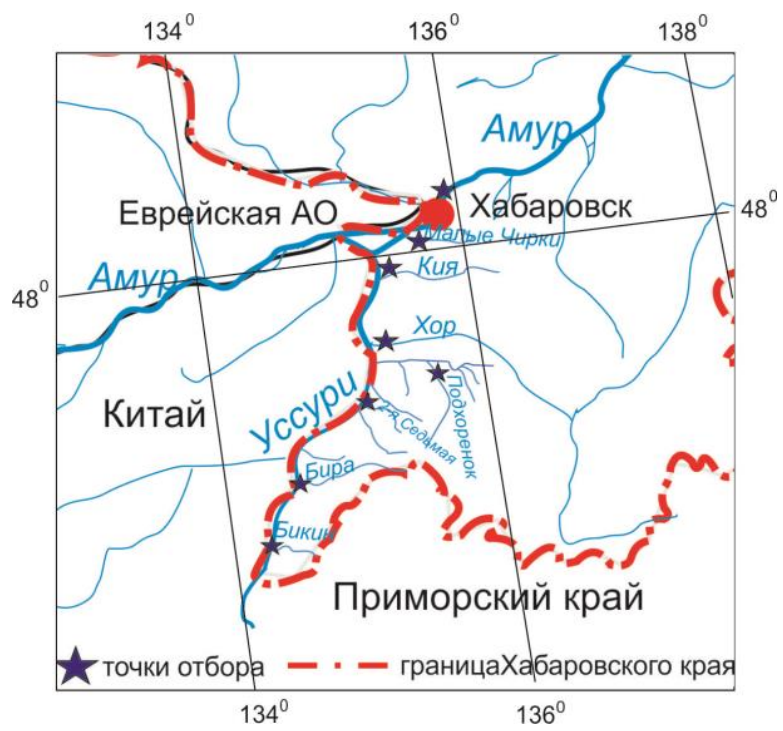

Рис. 1. Схема расположения исследуемых объектов южной части Хабаровского края

Fig. 1. Schematic map of rivers of southern Khabarovsk region that have been sampled. Stars - water sampling stations, red line - Khabarovsk region border 

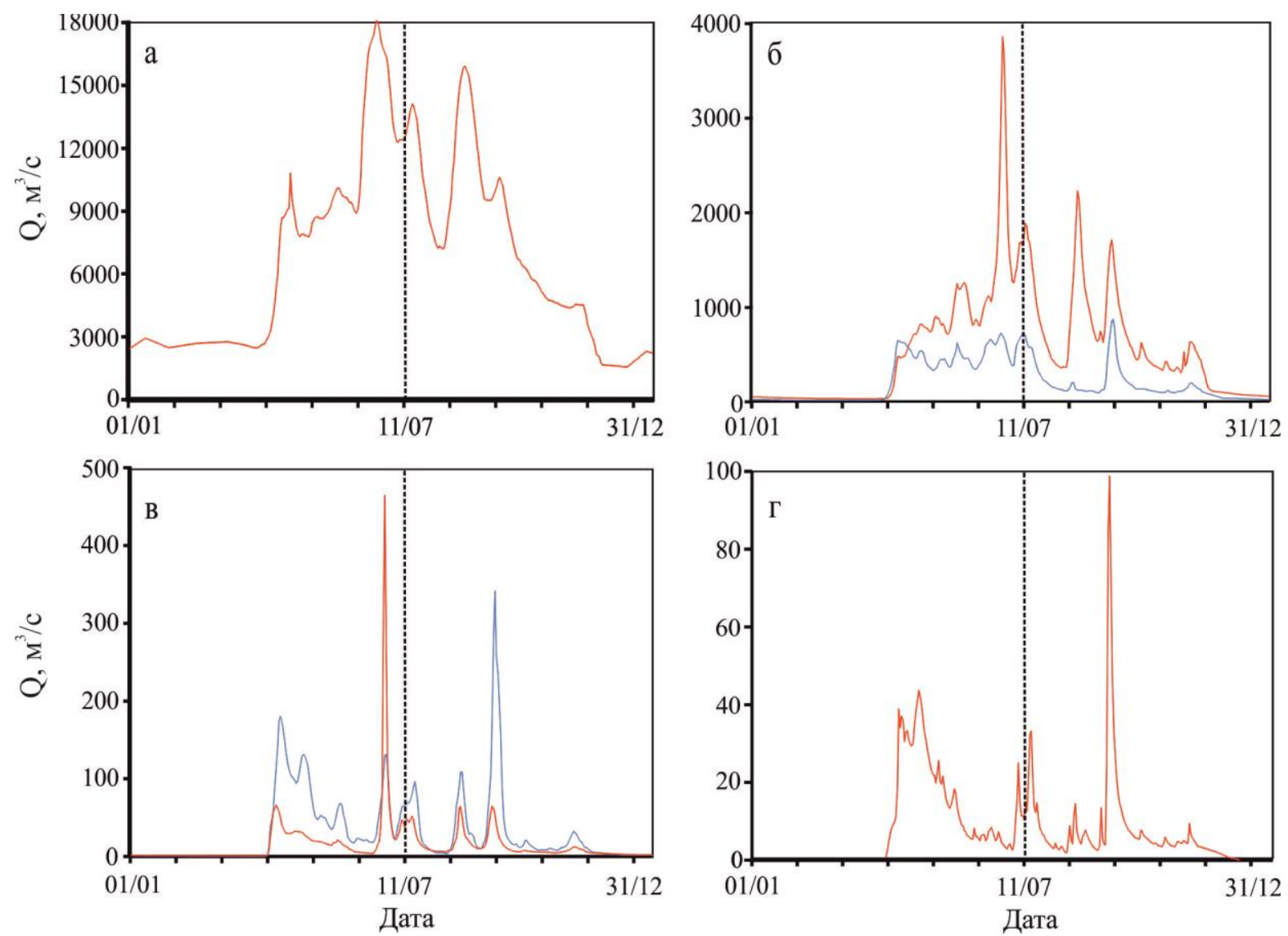

Pис. 2. Расходы воды в реках южной части Хабаровского края в 2011 г.: а) Амур; б) Хор (красная линия), Бикин (синяя линия); в) Подхоренок (красная линия), Кия (синяя линия); г) Бира. Пунктирная линия - дата отбора

Fig. 2. Daily river discharges in 2011: a) Amur; б) Khor (red line), Bikin (blue line); в) Podkhorenok (red line), Kiya (blue line); г) Bira. Dotted line - sampling date

Питание рек Хабаровского края главным образом дождевое, летне-осенние муссонные дожди формируют до 75 \% годового стока. На юге края с апреля по октябрь выпадает до $90 \%$ осадков, особенно много их в июле. Роль снегового питания в весенние месяцы не превышает 7 \% [10]. Благодаря муссонному климату расходы рек существенно зависят от сезона. Характерными чертами гидрологического режима рек Хабаровского края, судя по данным многолетних наблюдений, являются слабо выраженное весеннее половодье, высокие, следующие один за другим, летние паводки и низкая зимняя межень [13].

Расходы воды в исследуемых реках в 2011 г. по данным Автоматизированной информационной системы государственного мониторинга водных объектов (АИС ГМВО) [14] показаны на рис. 2. Для рек Малая Чирка и 2-я Седьмая расходы не найдены. Из рис. 2 видно, что отбор проб пришелся на период пика паводка средней водности.

\section{Результаты и обсуждение}

Основной солевой состав

Концентрации параметров ОСС в речных водах, а также площади водосбора и расхода воды изученных рек приведены в табл. 1.

Суммарная аналитическая погрешность определения главных ионов была оценена с помощью величи- ны нормализованного зарядного баланса ионов NICB (normalized inorganic charge balance):

$$
\operatorname{NICB}(\%)=\left(\mathrm{TZ}^{+}-\mathrm{TZ}^{-}\right) / \mathrm{TZ}^{+} \times 100 \text {, }
$$

где

$$
\begin{gathered}
\mathrm{TZ}^{+}=\left[\mathrm{Na}^{+}\right]+\left[\mathrm{K}^{+}\right]+2\left[\mathrm{Ca}^{2+}\right]+2\left[\mathrm{Mg}^{2+}\right] \\
\text { и } \mathrm{TZ}^{-}=2\left[\mathrm{SO}_{4}{ }^{2-}\right]+\left[\mathrm{Cl}^{-}\right]+\left[\mathrm{HCO}_{3}^{-}\right] .
\end{gathered}
$$

Здесь в скобках - концентрации параметров ОСС в размерности мкмоль/л. Величины NICB для всех исследуемых рек, кроме р. Малая Чирка и р. 2-я Седьмая, не превышают $3 \%$. Такое небольшое несоответствие в суммах анионов и катионов определяется, как правило, суммарной погрешностью измерения главных ионов и вполне допустимо, особенно для рек с низкой минерализацией [15]. Несколько большее нарушение зарядного баланса в реках Малая Чирка и 2-я Седьмая (соответственно +4,2 и $+5,8$ \%) связано, по мнению авторов, с присутствием в пробах «не учтенных» анионов: возможно, нитратов, фосфатов, органических кислот. Оценить количественно вклад этих анионов в величину $\mathrm{TZ}^{-}$невозможно, так как они не были проанализированы в отобранных пробах.

Анализ полученных данных показал, что во всех рассмотренных реках поверхностные воды в период пика паводка 2011 г. были ультрапресными. В шести из восьми рассмотренных рек значения $\sum_{i}$ не превышали 40 мг/л, а в реках 2-я Седьмая и Амур 
$\sum_{i}$ 50 мг/л (табл. 1). Доступные нам исторические данные указывают на низкую минерализацию поверхностных вод Хабаровского края не только во время паводков, но и в другие периоды гидрологического режима [14]. В реках Бира, Кия, Бикин, Хор даже в период зимней межени значения $\sum_{i}$ не превышали 60 мг/л. Эта особенность достаточно однородного сезонного распределения $\sum_{i}$ характерна для малых и наиболее чистых рек юга Дальнего Востока РФ [16].

Таблица 1. Площадь водосбора (S), расход воды (Q), общая минерализация $\left(\sum_{i}\right)$ и конщентрации ионов основного солевого состава в реках юга Хабаровского края (11.07.2011)

Table 1. Drainage area $(S)$, discharge $(Q)$, total mineralization $\left(\sum_{i}\right)$, and major element concentrations in the rivers of southern Khabarovsk region (11.07.2011)

\begin{tabular}{|c|c|c|c|c|c|c|c|c|c|c|}
\hline \multirow{2}{*}{$\begin{array}{l}\text { Река } \\
\text { River }\end{array}$} & \multirow{2}{*}{$\underset{\mathrm{M}^{3} / \mathrm{c} / \mathrm{m}^{3} / \mathrm{s}}{Q,}$} & \multirow{2}{*}{$\begin{array}{c}S, \\
10^{3} \mathrm{Km}^{2} / 10^{3} \mathrm{~km}^{2}\end{array}$} & \multirow{2}{*}{$\sum_{\mathrm{M \Gamma} / \mathrm{I} / \mathrm{mg} / \mathrm{l}}$} & $\mathrm{Na}^{+}$ & $\mathrm{K}^{+}$ & $\mathrm{Ca}^{2+}$ & $\mathrm{Mg}^{2+}$ & $\mathrm{Cl}^{-}$ & $\mathrm{SO}_{4}{ }^{2-}$ & $\mathrm{HCO}_{3}$ \\
\hline & & & & \multicolumn{7}{|c|}{$\mathrm{MKM} / \mu \mathrm{M}$} \\
\hline Бира/Bira & 15 & 0,728 & 35,74 & 141,4 & 23,5 & 107,8 & 48,6 & 44,3 & 40,6 & 338 \\
\hline Амур/Amur & 12400 & 1855 & 50,62 & 171,8 & 28,9 & 160,7 & 67,5 & 44,8 & 25,4 & 548 \\
\hline Кия/Кiуa & 37,5 & 0,829 & 38,07 & 114,4 & 25,6 & 123,2 & 53,5 & 39,5 & 22,9 & 403 \\
\hline Xop/Khor & 1730 & 24,50 & 33,97 & 109,6 & 23,8 & 108,0 & 41,1 & 26,8 & 31,6 & 347 \\
\hline Подхоренок/Podkhorenok & 64,3 & 2,33 & 37,32 & 124,8 & 24,8 & 116,5 & 56,0 & 35,5 & 34,8 & 374 \\
\hline Бикин/Bikin & 726 & 21,40 & 35,75 & 84,0 & 18,4 & 132,5 & 55,1 & 40,0 & 35,7 & 354 \\
\hline Малая Чирка/Malaya Chirka & отс. & отс. & 39,74 & 150,5 & 26,6 & 125,0 & 52,7 & 54,2 & 30,5 & 395 \\
\hline 2-я Седьмая/2-уа Sedmaya & отс. & отс. & 46,84 & 136,6 & 26,9 & 159,2 & 73,2 & 33,8 & 29,5 & 499 \\
\hline
\end{tabular}

Химический состав речных вод зависит от многих факторов: рельефа, климата, состава геологических пород на водосборе, антропогенного воздействия [17] Так, минерализация вод малых таежных рек севера Хабаровского края (Буреинское нагорье, хр. Турана, Дуссе-Аминь и др.) редко превышает 20 мг/л [6]. Этому способствует распространение на их водосборной площади интрузивных пород разного состава и возраста, которые трудно выщелачиваются, многолетняя мерзлота, препятствующая питанию рек грунтовыми водами, а также отсутствие крупных населенных пунктов - основных источников антропогенного загрязнения. На юге края минерализация поверхностных вод в 2 раза выше, что, на наш взгляд, в большей степени связано с составом подстилающих пород. Там преобладают разновозрастные осадочные и вулканогенно-осадочные породы, крупные массивы известняков и доломитов, карст $[6,18]$.

В рассмотренный период наблюдений обнаружено однородное распределение параметров ОСС в поверхностных водах исследованного региона. На это указывают низкие значения стандартных отклонений от средних величин относительного содержания катионов и анионов (в мкэкв/л), рассчитанных для всех рассматриваемых рек. Среди катионов в исследуемых реках доминирует $\mathrm{Ca}^{2+}$, среднее отношение $\mathrm{Ca}^{2+} / \mathrm{TZ}^{+}=0,493 \pm 0,031$. Средние отношения $\mathrm{Na}^{+} / \mathrm{TZ}^{+}$, $\mathrm{Mg}^{2+} / \mathrm{TZ}^{+} \quad$ и $\mathrm{K}^{+} / \mathrm{TZ}^{+}$составляли $0,246 \pm 0,038$, $0,213 \pm 0,016$ и $0,048 \pm 0,005$, соответственно. Основным противо-ионом для катионов во всех реках является $\mathrm{HCO}_{3}^{-}$, среднее отношение $\mathrm{HCO}_{3}^{-} / \mathrm{TZ}^{-}=0,795 \pm 0,042$. Средние отношения $\mathrm{SO}_{4}{ }^{2-} / \mathrm{TZ}^{-}$и $\mathrm{Cl}^{-} / \mathrm{TZ}^{-}$составляли $0,126 \pm 0,034$ и $0,079 \pm 0,017$, соответственно. Таким образом, в период летнего паводка 2011 г. вода во всех реках была однотипна - гидрокарбонатнокальциевая, что указывает на однородность источников питания рек юга Хабаровского края. Высокие концентрации ионов $\mathrm{Ca}^{2+}$ и $\mathrm{HCO}_{3}^{-}$указывают на процессы выветривания карбонатных пород в бассейнах рассмотренных рек:

$$
\mathrm{CaCO}_{3}+\mathrm{H}_{2} \mathrm{CO}_{3} \rightarrow \mathrm{Ca}^{2+}+2 \mathrm{HCO}_{3}^{-}
$$

$$
\mathrm{CaMg}\left(\mathrm{CO}_{3}\right)_{2}+2 \mathrm{H}_{2} \mathrm{CO}_{3} \rightarrow \mathrm{Ca}^{2+}+\mathrm{Mg}^{2+}+4 \mathrm{HCO}_{3}^{-} \text {. }
$$

Согласно реакциям (1) и (2), стехиометрические молярные отношения $\mathrm{Ca}^{2+} / \mathrm{HCO}_{3}^{-}$и $\left(\mathrm{Ca}^{2+}+\mathrm{Mg}^{2+}\right) / \mathrm{HCO}_{3}^{-}$ в продуктах карбонатного выветривания должны быть близки к 0,5 . В рассмотренных реках средние величины $\mathrm{Ca}^{2+} / \mathrm{HCO}_{3}^{-}$и $\left(\mathrm{Ca}^{2+}+\mathrm{Mg}^{2+}\right) / \mathrm{HCO}_{3}^{-}$равны $0,32 \pm 0,02$ и $0,46 \pm 0,03$, соответственно. Эти данные указывают на выветривание магнезиальных карбонатных минералов в бассейнах рек юга Хабаровского края в период высокого расхода воды. Известно, что интенсивность процессов химического выветривания в речных бассейнах возрастает с увеличением расхода воды и количества атмосферных осадков в регионе [19].

Среднее молярное $\mathrm{Ca}^{2+} / \mathrm{Mg}^{2+}$ отношение в исследованных речных водах равно 2,32 $\pm 0,17$. Это значение ниже величины $\mathrm{Ca}^{2+} / \mathrm{Mg}^{2+}$ в палеозойских карбонатах, равной $\sim 5,2$, но в два раза выше средней вели-

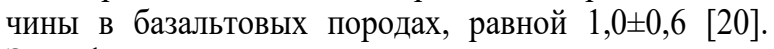
Этот факт указывает на присутствие в речных водах юга Хабаровского края продуктов выветривания не только карбонатных, но и силикатных пород. Величины $\mathrm{Ca}^{2+} / \mathrm{Na}^{+}, \mathrm{Mg}^{2+} / \mathrm{Na}^{+}$и $\mathrm{HCO}_{3}{ }^{-} / \mathrm{Na}^{+}$молярных отношений в исследованных речных водах также указывают на влияние продуктов выветривания силикатных пород на химический состав речных вод региона:

$$
\mathrm{CaSiO}_{3}+2 \mathrm{CO}_{2}+3 \mathrm{H}_{2} \mathrm{O} \rightarrow 2 \mathrm{HCO}_{3}^{-}+\mathrm{Ca}^{2+}+\mathrm{H}_{4} \mathrm{SiO}_{4} \text {. }
$$

Возможно также химическое выветривание глинистых минералов, например, превращение Са-плагиоклаза в каолинит [21, 22]:

$$
\begin{gathered}
2 \mathrm{CO}_{2}+2 \mathrm{CaAl}_{2} \mathrm{Si}_{2} \mathrm{O}_{8}(\mathrm{Tв})+3 \mathrm{H}_{2} \mathrm{O} \rightarrow \mathrm{Al}_{2} \mathrm{Si}_{2} \mathrm{O}_{5}(\mathrm{OH})_{4}(\mathrm{Tв})+ \\
\mathrm{Ca}\left(\mathrm{HCO}_{3}\right)_{2} \text { (раствор). }
\end{gathered}
$$

Таким образом, поступающие в реки с грунтовыми водами продукты выветривания карбонатных и силикатных пород играют важную роль в формировании химического состава поверхностных вод юга Хабаровского края.

Важной величиной, характеризующей экспорт растворенных веществ реками в приемные бассейны, является величина ионного потока (или потока глав- 
ных ионов), поскольку ионный поток $\left(J_{i}\right)$ составляет основную массу переносимых рекой веществ $[15,19]$ Поток растворенного вещества также широко используется в литературе как индикатор скорости химического выветривания [20, 22].

На основании полученных данных о расходе воды и концентрации главных ионов в исследуемых реках были рассчитаны их абсолютные суточные потоки $\left(J_{i}\right)$

$$
J_{i}=Q \times C,
$$

где $Q$ - расход реки, $C$ - концентрация ионов или их сумма $\left(\sum_{i}\right)$ в мг/л.

Как видно из приведенной формулы, все закономерности ионного стока целиком связаны с особенностями величин водного стока и минерализации воды. Этот факт указывает на сильную зависимость ионного стока от водоносности рек. По поводу характера этой зависимости высказываются различные мнения. Так, О.А. Алекин полагал, что полной пропорцио- нальности между ионным и водным стоками не может быть из-за различия в минерализации воды [15]. Однако в работе [19] обнаружена прямая пропорциональность между потоками $\mathrm{HCO}_{3}^{-}$и расходом воды для 4-х крупных рек мира с различными гидрологическими режимами: Янцзы, Хуанхэ, Жемчужной и Миссисиппи. Авторы объясняют этот факт процессами химического выветривания породообразующих минералов в бассейнах этих рек, интенсивность которых возрастает с увеличением расхода воды и количества атмосферных осадков в регионе.

В табл. 2 приведены рассчитанные по уравнению (3) величины суточных потоков главных ионов. Величины $J_{\sum i}$ в исследованных реках в период летнего паводка изменялись в значительных пределах: от 46 т/сут в реке с минимальным расходом (р. Бира) до $\sim 54$ тыс. т/сут в реке с максимальным расходом (р. Амур) (табл. 2).

Таблица 2. Потоки $(\mathrm{m} / \mathrm{cym})$ ионов основного солевого состава и суммарные суточные потоки макро-ионов $\left(J_{\Sigma i}\right)$, микроэлементов $\left(\sum_{м \ni}\right)$ и редкоземельных элементов $\left(\sum_{p з э}\right)$ в некоторых реках юга Хабаровского края (11.07.2011)

Table 2. Daily fluxes (t/day) of major elements and total daily fluxes of major elements $\left(J_{\Sigma j}\right)$, trace elements $\left(\sum_{T E}\right)$, and rare earth elements $\left(\sum_{R E E}\right)$ in southern Khabarovsk region rivers (11.07.2011)

\begin{tabular}{|c|c|c|c|c|c|c|c|c|c|c|}
\hline $\begin{array}{l}\text { Река } \\
\text { River }\end{array}$ & $\mathrm{J}_{\sum \mathrm{i}}$ & $\mathrm{J}_{\mathrm{Na}}^{+}$ & $\mathrm{J}_{\mathrm{K}}^{+}$ & $\mathrm{J}_{\mathrm{Ca}}{ }^{2+}$ & $\mathrm{J}_{\mathrm{Mg}}{ }^{2+}$ & $\mathrm{J}_{\mathrm{Cl}}{ }^{-}$ & $\mathrm{J}_{\mathrm{SO} 4}{ }^{2-}$ & $\mathrm{J}_{\mathrm{HCO}^{-}}^{-}$ & $\begin{array}{l}\sum_{\sum_{\mathrm{M} \ni}} \\
\left(\sum_{\mathrm{TE}}\right)\end{array}$ & $\begin{array}{c}\sum_{\mathrm{P} 33} \\
\left(\sum_{\mathrm{REE}}\right)\end{array}$ \\
\hline Бира/Bira & 46,56 & 4,2 & 1,2 & 5,6 & 1,5 & 2,0 & 5,1 & 26,8 & 0,80 & 0,0033 \\
\hline Амур/Amur & 54214 & 4230 & 1210 & 6897 & 1756 & 1703 & 2613 & 35804 & 294 & 1,711 \\
\hline Кия/Кiуа & 122 & 8,4 & 3,2 & 15,8 & 4,2 & 4,5 & 7,0 & 78,7 & 1,88 & 0,0047 \\
\hline Xop/Khor & 5061 & 375 & 139 & 645 & 149 & 142 & 453 & 3159 & 45,8 & 0,319 \\
\hline Подхоренок/Podkhorenok & 209 & 16,1 & 5,4 & 26,1 & 7,6 & 7,1 & 18,7 & 128 & 5,47 & 0,023 \\
\hline Бикин/Bikin & 2241 & 121 & 45,4 & 333 & 84,0 & 89,0 & 215 & 1354 & 28,70 & 0,148 \\
\hline
\end{tabular}

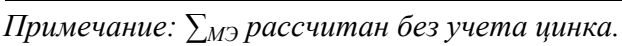

Note: $\sum_{T E}$ was calculated without $\mathrm{Zn}$.

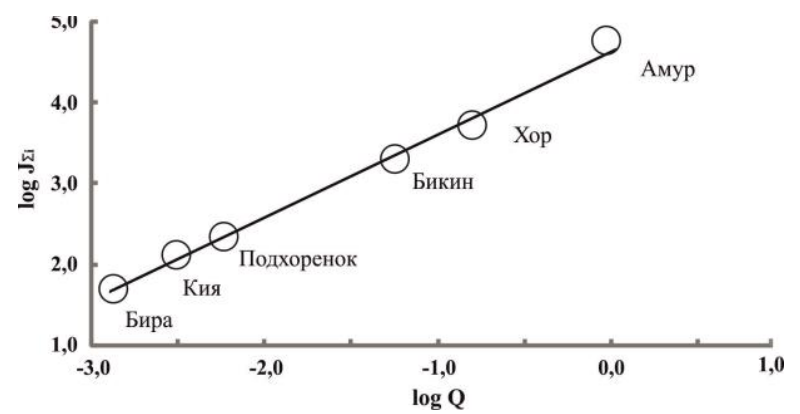

Рис. 3. Сравнительная характеристика суточного ионного потока $\left(J_{\sum i}, \mathrm{~m} / \mathrm{cym}\right)$ и водного стока $(Q$, $\left.\mathrm{\kappa м}^{3} / \mathrm{cym}\right)$ в реках Хабаровского края в период летнего паводка. Коррелячия приведена в log-log шкалах. Линия регрессии: $\log J_{\sum i}=1,031 \times \log Q+4,632$ $\left(R^{2}=0,998\right)$

Fig. 3. Correlation between total daily flux of major elements $\left(J_{\sum i}, t / d a y\right)$ and discharge $\left(Q, \mathrm{~km}^{3} /\right.$ day $)$ in the rivers of southern Khabarovsk region during summer flood. Correlation is shown in log-log scales. Regression line: $\log J_{\Sigma i}=1,031 \times \log Q+4,632$ $\left(R^{2}=0,998\right)$

Из-за малого количества данных мы не можем установить сезонный характер связи ионного и водного стоков для каждой из рассмотренных в этой работе рек. Однако в период летнего паводка 2011 г. для поверхностных вод исследуемой территории Хабаровского края, представленной реками Бира, Кия, Подхоренок, Бикин, Хор и Амур, обнаружена прямая пропорциональность $\left(R^{2}=0,993-0,998\right)$ между логарифмами потоков всех главных ионов и логарифмами расхода воды. В качестве примера на рис. 3 показана сравнительная характеристика логарифмов суммарного суточного потока макро-ионов $\left(J_{\sum i}\right.$, т/сут) и суточного водного стока $\left(Q, \mathrm{kM}^{3} /\right.$ сут) в этих реках. Этот результат подтверждает наш вывод об однородности источников питания рек юга Хабаровского края в период высокого расхода воды и обильных атмосферных осадков.

\section{Микроэлементный состав}

Микроэлементы более подвержены фракционированию в процессах химического выветривания и транспорта растворенных веществ, чем макроэлементы, что дает основание использовать их при изучении природы и интенсивности указанных процессов $[11,23]$. Концентрации растворенных форм 16-ти микроэлементов в водах изученных рек приведены в табл. 3 .

Мы не смогли найти объяснение экстремально высоким величинам концентрации растворенного цинка $(\mathrm{Zn})$ в исследуемых реках. Реальным выглядит только величина 16 мкг/л, обнаруженная в р. Амур (табл. 3). 
В остальных реках измеренные концентрации в десятки, сотни и даже тысячи раз выше, чем в р. Амур (табл. 3). Высокие концентрации Zn ранее были обнаружены в некоторых малых реках Хабаровского края, но они не превышали 40-60 мкг/л $[8,9]$. Измеренные нами концентрации $\mathrm{Zn}$ в реках Бира и Малая Чирка, равные 10 и 115 мг/л, соответственно, на несколько порядков выше и сопоставимы с концентрациями в наиболее загрязненных реках мира, которые расположены на юге Испании в области сульфидной минерализации и промышленно развитой городской территории $[24,25]$. По этой причине концентрации $\mathrm{Zn}$ приведены в табл. 3, но исключены из рассмотрения для характеристики региональных особенностей микроэлементного состава рек юга Хабаровского края.

В поверхностных водах всех 8-ми исследованных рек обнаружены высокие концентрации и других микроэлементов: растворенного алюминия (Al), железа $(\mathrm{Fe})$ и свинца $(\mathrm{Pb})$. Минимальная концентрация $\mathrm{Al}$, равная 53 мкг/л, была определена в р. Амур. Эта величина почти в 2 раза выше средней концентрации в речных водах [24], но хорошо согласуется со средним содержанием алюминия в бассейне р. Уссури на территории Приморского края, равным 52 мкг/л [11]. Максимальные концентрации Al (230 мкг/л) обнаружены в реках Подхоренок, Малая Чирка и 2-я Седьмая (табл. 3). Минимальные концентрации $\mathrm{Fe}$, не превышающие 200 мкг/л, были получены в реках Амур, Хор и Бира, а максимальные (400-670 мкг/л) - в реках 2-я Седьмая, Малая Чирка и Подхоренок (табл. 3) Эти величины превышают средние концентрации речных вод $[23,24]$ в 3-10 раз. Содержание $\mathrm{Pb}$ в p. Малая Чирка превышает среднюю концентрацию речных вод почти в 100 раз, в р. Подхоренок - в 13 раз, в остальных реках - в 5-10 раз (табл. 3). В р. Малая Чирка превышены концентрации растворенного кадмия $(\mathrm{Cd})$, кобальта $(\mathrm{Co})$, меди $(\mathrm{Cu})$ и марганца (Mn): по сравнению со средними значениями $[23,24]$ в 43, 6,9 и 3 раза, соответственно (табл. 3 ).

Таблица 3. Концентрации растворимых форм микроэлементов в реках юга Хабаровского края (мкг/л) (11.07.2011)

Table 3. Dissolved trace element concentrations in the rivers of southern Khabarovsk region ( $\mu g / l)(11.07 .2011)$

\begin{tabular}{|c|c|c|c|c|c|c|c|c|c|}
\hline $\begin{array}{l}\text { Элемент } \\
\text { Element }\end{array}$ & $\begin{array}{l}\text { Амур } \\
\text { Amur }\end{array}$ & $\begin{array}{l}\text { Xop } \\
\text { Khor }\end{array}$ & $\begin{array}{l}\text { Малая Чирка } \\
\text { Malaya Chirka }\end{array}$ & $\begin{array}{l}\text { Подхоренок } \\
\text { Podkhorenok }\end{array}$ & $\begin{array}{l}\text { Кия } \\
\text { Kiya } \\
\end{array}$ & $\begin{array}{c}\text { 2-я Седьмая } \\
\text { 2-уа Sedmaya }\end{array}$ & $\begin{array}{l}\text { Бира } \\
\text { Bira }\end{array}$ & $\begin{array}{l}\text { Бикин } \\
\text { Bikin }\end{array}$ & $\begin{array}{l}\text { Среднее } \\
\text { Average }\end{array}$ \\
\hline $\mathrm{Cd}$ & 0,01 & 0,041 & 3,5 & 0,025 & 0,031 & 0,038 & 0,061 & 0,017 & 0,08 \\
\hline $\mathrm{Cr}$ & 0,27 & 0,46 & 0,74 & 0,84 & 0,39 & 0,72 & 0,92 & 0,58 & 0,70 \\
\hline $\mathrm{Cu}$ & 1,4 & 2,2 & 13,1 & 2,7 & 1,7 & 2,7 & 2,0 & 1,9 & 1,5 \\
\hline $\mathrm{Fe}$ & 165 & 170 & 469 & 669 & 381 & 412 & 396 & 275 & 66 \\
\hline $\mathrm{Mn}$ & 6,5 & 7,1 & 103 & 37 & 61 & 24 & 16,2 & 12,2 & 34 \\
\hline $\mathrm{Pb}$ & 0,38 & 0,68 & 7,5 & 1,1 & 0,79 & 0,68 & 1,1 & 0,59 & 0,079 \\
\hline $\mathrm{Sr}$ & 36 & 25 & 35 & 29 & 36 & 49 & 43 & 35 & 60 \\
\hline $\mathrm{Ba}$ & 10,2 & 7,6 & 21,1 & 15,8 & 25,1 & 15,8 & 9,9 & 7,5 & 23 \\
\hline $\mathrm{Zn}$ & 16 & 949 & 115100 & 145 & 459 & 1280 & 10750 & 174 & 0,6 \\
\hline $\mathrm{Be}$ & 0,017 & 0,017 & 0,037 & 0,036 & 0,015 & 0,024 & 0,027 & 0,023 & 0,009 \\
\hline $\mathrm{V}$ & 0,51 & 0,51 & 0,70 & 0,69 & 0,47 & 0,86 & 1,1 & 0,64 & 0,71 \\
\hline $\mathrm{Al}$ & 53,3 & 92 & 232 & 226 & 72 & 221 & 142 & 124 & 32 \\
\hline $\mathrm{Rb}$ & 0,69 & 0,76 & 1,1 & 0,64 & 0,94 & 0,68 & 0,72 & 0,55 & 1,6 \\
\hline $\mathrm{Tl}$ & 0,003 & 0,006 & 0,015 & 0,004 & 0,005 & 0,006 & 0,02 & 0,004 & 0,007 \\
\hline $\mathrm{Co}$ & 0,06 & 0,085 & 0,86 & 0,25 & 0,26 & 0,20 & 0,15 & 0,22 & 0,15 \\
\hline $\mathrm{Ag}$ & 0,002 & 0,004 & 0,01 & 0,007 & 0,003 & 0,005 & 0,004 & 0,005 & H.o. \\
\hline
\end{tabular}

Примечание: в качестве средних концентраций использовали данные [24].

Note: average concentrations are taken from [24].

Установление природного фона всех тяжелых металлов является сложной задачей, поскольку эти элементы широко используются в хозяйственной деятельности и являются основными загрязнителями окружающей среды $[11,23]$. В этой связи интересно распределение $\mathrm{Al}$ в реках юга Хабаровского края. Известно, что алюминий почти не подвержен влиянию антропогенного фактора, мало растворим и является продуктом эрозии земной поверхности [23]. В исследуемых реках концентрация $\mathrm{Al}$ изменяется от 53 мкг/л в р. Амур до 230 мкг/л в реках Подхоренок, Малая Чирка и 2-я Седьмая (табл. 3). Содержание остальных микроэлементов в исследуемых реках в целом соответствовало их средним концентрациям $[23,24]$ и является, таким образом, характеристикой природного регионального фона в период летних паводков.

На основании полученных данных о расходе воды и концентрации растворенных микроэлементов в ис- следуемых реках по уравнению (3) были рассчитаны их абсолютные суточные потоки $\left(J_{\mathrm{M}}\right)$. В табл. 2 приведены величины суммарных суточных потоков рас-

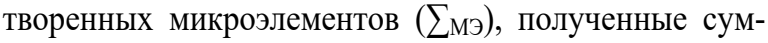
мированием потоков всех измеренных микроэлементов, кроме Zn. Следует отметить, что 99 \% величин $\sum$ мэ во всех рассмотренных реках (в отсутствии цинка) составляет вклад растворенных алюминия, железа, марганца, бария и стронция.

\section{Редкоземельные элементь}

Степень изученности РЗЭ в речных водах Хабаровского края слабая, отрывочные данные по некоторым РЗЭ существуют в литературе только для реки Амур [7]. Полученные в этой работе результаты являются первыми комплексными исследованиями в этой области.

Региональный уровень растворенных форм РЗЭ в речных водах юга Хабаровского края изменяется от 
1,44 (р. Кия) до 5,44 мкг/л (р. Малая Чирка) (табл. 4). Средние содержания РЗЭ в исследуемых водах составляют от 2,13 до 2,81 мкг/л. При этом во всех изученных реках концентрации легких РЗЭ выше, чем тяжелых и составляют 81-85\% от суммарных концентраций.

Таблица 4. Содержание растворимых форм редкоземельных элементов (мкг/л) в реках юга Хабаровского края (11.07.2011)

Table 4. Concentration of REE in the rivers ( $\mu \mathrm{g} / \mathrm{l})$ of southern Khabarovsk region (11.07.2011)

\begin{tabular}{|c|c|c|c|c|c|c|c|}
\hline $\begin{array}{c}\text { Элемент } \\
\text { Element }\end{array}$ & $\begin{array}{c}\text { Бира } \\
\text { Bira }\end{array}$ & $\begin{array}{c}\text { Подхоренок } \\
\text { Pokhorenok }\end{array}$ & $\begin{array}{c}\text { Малая Чирка } \\
\text { Маlaya Chirka }\end{array}$ & $\begin{array}{c}\text { Кия } \\
\text { Кiуa }\end{array}$ & $\begin{array}{c}\text { Хор } \\
\text { Кhor }\end{array}$ & $\begin{array}{c}\text { Aмур } \\
\text { Amur }\end{array}$ & $\begin{array}{c}\text { Бикин } \\
\text { Bikin }\end{array}$ \\
\hline $\mathrm{Eu}$ & 0,03 & 0,051 & 0,053 & 0,019 & 0,024 & 0,018 & 0,029 \\
\hline $\mathrm{Ce}$ & 0,808 & 1,27 & 1,97 & 0,425 & 0,611 & 0,478 & 0,702 \\
\hline $\mathrm{Pr}$ & 0,131 & 0,222 & 0,271 & 0,079 & 0,117 & 0,084 & 0,125 \\
\hline $\mathrm{Sm}$ & 0,121 & 0,217 & 0,243 & 0,075 & 0,113 & 0,082 & 0,128 \\
\hline $\mathrm{Ho}$ & 0,019 & 0,038 & 0,039 & 0,012 & 0,018 & 0,013 & 0,02 \\
\hline $\mathrm{Gd}$ & 0,122 & 0,224 & 0,258 & 0,075 & 0,118 & 0,087 & 0,131 \\
\hline $\mathrm{Tb}$ & 0,018 & 0,033 & 0,037 & 0,01 & 0,017 & 0,012 & 0,018 \\
\hline $\mathrm{Lu}$ & 0,008 & 0,014 & 0,012 & 0,005 & 0,007 & 0,005 & 0,007 \\
\hline $\mathrm{Dy}$ & 0,098 & 0,194 & 0,201 & 0,057 & 0,093 & 0,068 & 0,102 \\
\hline $\mathrm{Er}$ & 0,055 & 0,106 & 0,103 & 0,034 & 0,05 & 0,039 & 0,058 \\
\hline $\mathrm{Nd}$ & 0,56 & 0,96 & 1,13 & 0,349 & 0,505 & 0,372 & 0,551 \\
\hline $\mathrm{Tm}$ & 0,007 & 0,015 & 0,013 & 0,004 & 0,007 & 0,005 & 0,008 \\
\hline $\mathrm{Yb}$ & 0,049 & 0,095 & 0,083 & 0,029 & 0,043 & 0,033 & 0,049 \\
\hline $\mathrm{La}$ & 0,492 & 0,752 & 1,03 & 0,272 & 0,41 & 0,301 & 0,441 \\
\hline $\mathrm{HREE}$ & 0,406 & 0,769 & 0,8 & 0,244 & 0,376 & 0,281 & 0,423 \\
\hline $\mathrm{LREE}$ & 2,112 & 3,421 & 4,644 & 1,201 & 1,756 & 1,317 & 1,947 \\
\hline$\sum=\mathrm{L}+\mathrm{H}(\mathrm{REE})$ & 2,52 & 4,19 & 5,44 & 1,44 & 2,13 & 1,6 & 2,37 \\
\hline $\mathrm{HREE} \%$ & 16,1 & 18,3 & 14,7 & 16,9 & 17,6 & 17,6 & 17,8 \\
\hline $\mathrm{LREE} \%$ & 83,9 & 81,7 & 85,3 & 83,1 & 82,4 & 82,4 & 82,2 \\
\hline $\mathrm{Eu} / \mathrm{Eu} *$ & 1,12 & 1,05 & 0,96 & 1,15 & 0,94 & 0,96 & 1,02 \\
\hline $\mathrm{Y}$ & 0,47 & 0,91 & 0,95 & 0,29 & 0,44 & 0,34 & 0,5 \\
\hline $\mathrm{Ce} / \mathrm{Ce} *$ & 0,69 & 0,67 & 0,81 & 0,63 & 0,61 & 0,65 & 0,65 \\
\hline$(\mathrm{La} / \mathrm{Yb}) / \mathrm{n}$ & 0,97 & 0,77 & 1,2 & 0,91 & 0,92 & 0,89 & 0,87 \\
\hline
\end{tabular}

Примечание: LREE - сумма легких P3Э; $E u / E u^{*}=2^{*} E u^{*} /\left(S m^{*}+C d^{*}\right) ; \quad H R E E$ - сумма тяжельх P3Э; $\mathrm{Ce} / \mathrm{C} e^{*}=2 * C e^{*} /\left(\mathrm{La}^{*}+\mathrm{Pr}^{*}\right) \Sigma R E E-$ общая сумма P3Э.

Note: $\triangle R E E$ is the total amount of REE; LREE is the sum of lighy REE; HREE is the sum of heavy REE; $E u / E u^{*}=2 * E u^{*} /\left(S m^{*}+C d^{*}\right) ; C e / C e^{*}=2 * C e^{*} /\left(L a^{*}+P r^{*}\right)$

Содержание растворенных РЗЭ в речных водах в значительной степени зависит от состава геологических пород водосбора и процессов их выветривания [23]. Исследуемые воды обогащены легкими РЗЭ (табл. 4) и относятся, согласно классификации Ю.А. Балашова, к так называемым «лантановым водам», которые, как правило, дренируются кислыми породами [26].

Для сглаживания пилообразного характера профили распределения РЗЭ в исследованных речных водах были нормированы по отношению К североамериканскому сланцу [27] (рис. 4).

Сравнение РЗЭ для рек юга Хабаровского края с величинами в реках Приморского края [16] и средними для рек величинами [24] показано на рис. 4. Полученные данные схожи и сопоставимы между собой по конфигурации. Во всех реках, кроме р. Малая Чирка, показатель соотношений La/Ybn равен 0,77-0,97, что отражает небольшое обогащение вод тяжелыми РЗЭ и указывает на возрастание их миграционной способности в ряду $\mathrm{La}-\mathrm{Lu}$. В реке Малая Чирка $\mathrm{La} / \mathrm{Ybn}=1,20$. Все исследованные реки имеют четко выраженную отрицательную цериевую аномалию $(\mathrm{Ce} / \mathrm{Ce} *=0,61-0,81)$ (рис. 4), наличие которой в пресных водах определяется химическими свойствами церия. В трех реках (Амур, Малая Чирка и Хор) проявлена отрицательная европиевая аномалия $\left(\mathrm{Eu} / \mathrm{Eu}^{*}=0,94-0,96\right)$, а для остальных рек - положительная европиевая аномалия $\left(\mathrm{Eu} / \mathrm{Eu}^{*}=1,01-1,15\right)$. Однотипные профили РЗЭ в реках юга Хабаровского края различаются только величинами концентраций. Из всех рек выделяется р. Малая Чирка, где обнаружены самые высокие значения РЗЭ. Такое превышение концентраций РЗЭ в этой реке наводит на мысль о влиянии хозяйственной деятельности человека на состав ее вод. Во всех исследованных реках обнаружено накопление группы средних редкоземельных элементов, что характерно и для рек Приморского края [16] (рис. 4). Величины суммарных суточных потоков растворенных РЗЭ $\left(\sum\right.$ рзэ) приведены в табл. 2.

Таким образом, полученные данные по распределению и концентрациям РЗЭ в исследуемых реках указывают на однородность источника поступления РЗЭ. 


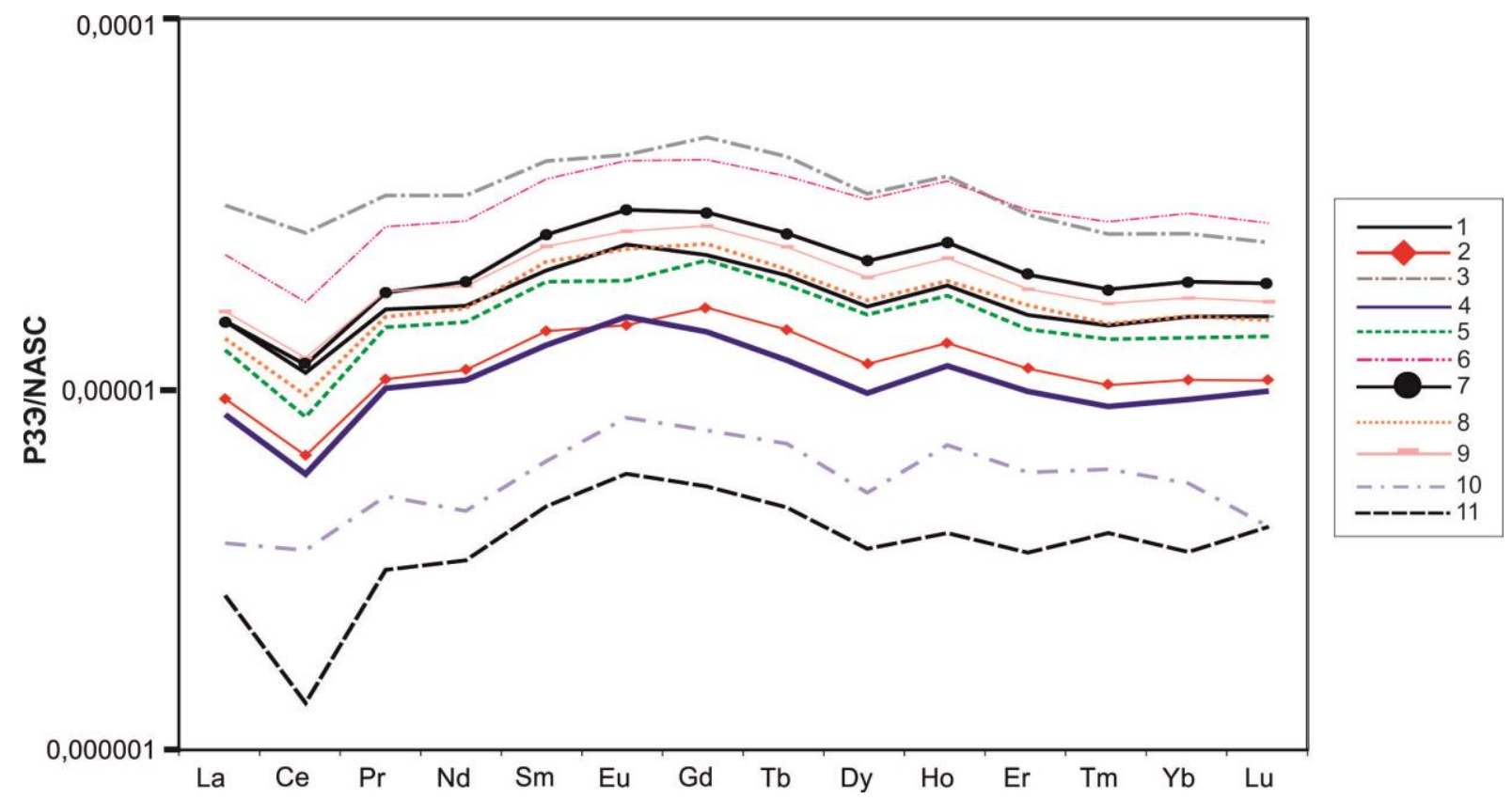

Рис. 4. Профили распределения концентраций редкоземельных элементов в реках юга Хабаровского края (1 - Бира; 2 -Амур; 3 - Малая Чирка, 4 - Кия; 5 -Хор; 6-Подхоренок; 7 - 2-ая Седьмая; 8 -Бикин; 9 - средние значения РЗЭ в южной части Хабаровского края; 10 - средние величины в реках [24]; 11 - средние конщентрации РЗЭ в Приморском крае [16])

Fig. 4. Profile distributions of rare earth element concentrations in the rivers of southern Khabarovsk region (1 - Bira, $2-$ Amur, 3 - Malaya Chirka, 4 -Kiya, 5-Khor, 6 -Podkhorenok, 7 - 2-aya Sedmaya, 8 - Bikin, 9 - southern Khabarovsk region averages; 10 - averages in the river waters [24]; 11 - southern Primorye averages [16])

\section{Заключение}

1. В июле 2011 г. проведены комплексные исследования гидрохимического стока 8-ми водных объектов юга Хабаровского края: р. Амур и семи рек бассейна Уссури (одного из наиболее значимых притоков Амура): Бикин, Хор, Подхоренок, Бира, Кия, Малая Чирка и 2-я Седьмая. В пробах речной воды были определены параметры основного солевого состава, микроэлементы и редкоземельные элементы.

2. В период высокого расхода воды в высоко увлажненных южных районах Хабаровского края речные воды очень схожи по типу и величине минерализации: среди катионов доминирует $\mathrm{Ca}^{2+}$, основным противо-анионом является $\mathrm{HCO}_{3}^{-}$; воды ультрапресные, величина минерализации не превышает 50 мг/л. Важную роль в формировании химического состава поверхностных вод юга Хабаровского края играют продукты выветривания карбонатных и силикатных пород, которые поступают в реки с грунтовыми водами.

3. В поверхностных водах всех исследованных рек обнаружены высокие концентрации растворенных форм $\mathrm{Al}, \mathrm{Fe}$ и $\mathrm{Pb}$. В р. Малая Чирка - высокие

\section{СПИСОК ЛИТЕРАТУРЫ}

1. Milliman J.D., Farnsworth K.L. River discharge to the coastal ocean. A global synthesis. - Cambridge: Cambridge university press, 2011. $-384 \mathrm{p}$.

2. Пространственные закономерности изменения химического состава и стока речных вод в бассейне Оби / О.Г. Савичев, концентрации растворенных $\mathrm{Co}, \mathrm{Cu}, \mathrm{Mn}$ и экстремально высокие - $\mathrm{Cd}$, превышающие средние глобальные концентрации в 40 раз. Содержание остальных микроэлементов в исследуемых реках в целом соответствует их средним речным концентрациям и является характеристикой природного регионального фона в период летнего паводка.

4. Установлен региональный уровень суммарных концентраций растворимых форм РЗЭ в реках юга Хабаровского края, который варьируется от 1,44 до 5,44 мкг/л. Полученные данные по распределению и концентрации Р3Э в исследуемых объектах указывает на однородность источника их поступления и отражает общий состав пород водосборного бассейна.

5. Рассчитанные суммарные суточные потоки компонентов ОСС, микроэлементов и редкоземельных элементов, поставляемые реками Бира, Кия, Подхоренок, Бикин, Хор и Амур, равны 61894, 377 и 2,21 т/сут, соответственно.

Работа выполнена при финансовой поддержке грантов РФФИ № 16-35-60098 мол_а_док., РФФИ № 16-05-00166.

А.К. Мазуров, И.И. Пипко, В.И. Сергиенко, И.П. Семилетов // ДАН. - 2016. - Т. 466. - № 2. - С. 202-206.

3. The spatial and interannual dynamics of the surface water carbonate system and air-sea $\mathrm{CO} 2$ fluxes in the outer shelf and slope of the Eurasian Arctic Ocean / I.I. Pipko, S.P. Pugach, I.P. Semiletov, L.G. Anderson, N.E. Shakhova, Ö. Gustafsson, 
I.A. Repina, E.A. Spivak, A.N. Charkin, A.N. Salyuk, K.P. Shcherbakova, E.V. Panova, O.V. Dudarev // Ocean Science. - 2017. - V. 13. - P. 997-1016.

4. Increasing alkalinity export from large Russian Arctic rivers T.W. Drake, S.E. Tank, A.V. Zhulidov, R.M. Holmes, T. Gurtovaya, R.G.-M. Spencer // Environmental Science and Technology. - 2018. - V. 52. - P. 8302-8308.

5. Шестеркин В.П., Шестеркина Н.М. Влияние крупных лесных пожаров на гидрохимический режим таежных рек Приамурья // География и природные ресурсы. - 2002. - № 2. - С. 47-52.

6. Форина Ю.А. Особенности химического состава воды малых рек северного Сихотэ-Алиня // Чтения памяти Владимира Яковлевича Леванидова. - 2011. - Вып. 5. - С. 557-562.

7. Шестеркин В.П., Шестеркина Н.М. Трансформация химического состава вод среднего Амура в зимнюю межень после трансграничного загрязнения 2005 года // География и природные ресурсы. - 2018. - № 1. - С. 52-58.

8. Государственный доклад о состоянии и об охране окружающей среды Хабаровского края в 2014 г. / под ред. В.М. Шихалева. - Хабаровск: ООО «ПРИНТ», 2015. - 219 с.

9. Государственный доклад о состоянии и об охране окружающей среды Хабаровского края в 2016 г. / под ред. А.Б. Ермолина. - Ижевск: ООО «ПРИН-2», 2017. - 226 с.

10. Состояние морских экосистем, находящихся под влиянием стока реки Амур / отв. ред. В.П. Челомин. - Владивосток: Дальнаука, 2009. - 238 с.

11. Чудаева В.А. Миграция химических элементов в водах Дальнего Востока. - Владивосток: Дальнаука, 2002. - 392 с.

12. Интеркалибрация метода Бруевича для определения общей щелочности в морской воде / Г.Ю. Павлова, П.Я. Тищенко, Т.И. Волкова и др. // Океанология. - 2008. - Т. 48. - № 3. C. $477-483$.

13. Многолетние данные о режиме и ресурсах поверхностных вод суши / под ред. Т.С. Шмидт. - Л.: Гидрометеоиздат, 1986. T. 1. - Вып. 21. -387 c.

14. Автоматизированная информационная система государственного мониторинга водных объектов (АИС ГМВО). URL: https://gmvo.skniivh.ru/ (дата обращения 12.01.2017).

15. Алекин О.А. Основы гидрохимии. - Л.: Гидрометиздат, 1970. $-444 \mathrm{c}$.

16. Основной солевой состав и редкоземельные элементы как индикаторы экологического состояния рек южного Приморья
Е.А. Вах, Г.Ю. Павлова, Т.А. Михайлик и др. // Изв. ТПУ. Инжиниринг георесурсов. - 2017. - Т. 328. - № 1. - С. 39-49.

17. Meybeck M. Global occurrence of major elements in rivers // Surface and ground water, weathering and soils. V. 5. Treatise of Geochemistry // Eds. H.D. Holland, K.K. Turekian et al. Amsterdam: Elsevier, 2004. - P. 207-223.

18. Берсенев Ю.И. Карст Дальнего Востока. - М.: Наука, 1989. $172 \mathrm{c}$.

19. A comparative overview of weathering intensity and $\mathrm{HCO}_{3}$ flux in the world's major rivers with emphasis on the Changiiang, Huanghe, Zhujiang (Pearl) and Mississippi Rivers / W.J. Cai, X. Guo, C.T.A. Chen et al. // Continental Shelf Research. 2008. - V. 28. - P. 1538-1549.

20. Global silicate weathering and $\mathrm{CO}_{2}$ consumption rates deduced from the chemistry of large rivers / J. Gaillardet, B. Dupre, P. Laouvat, C.J. Allegre // Chemical Geology. - 1999. - V. 159. P. 3-30.

21. Карбонатное равновесие вод реки Раздольной / П.Я. Тищенко, Т.А. Михайлик, Г.Ю. Павлова и др. // Геохимия. - 2017. T. 55. - № 3. - C. 236-248.

22. White A.F., Blum A.E. Effect of climate on chemical weathering in watersheds // Geochimica et cosmochimica acta. - 1995. V. 59. - P. 1729-1747.

23. Гордеев В.В. Геохимия системы река-море. - М.: И.П. Матушкина И.И., 2012. - 452 с.

24. Gaillardet J., Viers J., Dupre B. Trace elements in rivers waters // Treasure on Geochemistry. - Amsterdam: Elsevier Pergamon, 2004. - V. 5. - P. 225-272

25. Metal biogeochemistry in the Tinto-Odiel rivers (Southern Spain) and in the Dulf of Cadiz: a synthesis of the results of TOROS project / F. Elbaz-Poulichet, Ch. Braungardt, E. Achterberg et al. // Continental Shelf Research. - 2001. - V. 21. - P. 1961-1973.

26. Балашов Ю.А. Геохимия редкоземельных элементов. - М.: Наука, 1976. - $267 \mathrm{c}$.

27. The «North American shale composite»: its composition, major and trace element characteristics / L.P. Gromet, R.F. Dumek, L.A. Haskin, R.L. Korotev // Geochimica et Cosmochimica Acta. - 1984. - V. 48. - P. 2469-2482.

Поступила 14.01.2019 г.

\section{Информация об авторах}

Павлова Г.Ю., кандидат химических наук, ведущий научный сотрудник лаборатории гидрохимии, Тихоокеанский океанологический институт им. В.И. Ильичева Дальневосточного отделения Российской академии наук.

$\boldsymbol{B a x} \boldsymbol{E} . \boldsymbol{A}$., кандидат геолого-минералогических наук, научный сотрудник кафедры безопасности в чрезвычайных ситуациях и защиты окружающей среды, Дальневосточный федеральный университет; научный сотрудник лаборатории гидрохимии, Тихоокеанский океанологический институт им. В.И. Ильичева Дальневосточного отделения Российской академии наук.

Тищенко П.Я., доктор химических наук, заведующий лабораторией гидрохимии, Тихоокеанский океанологический институт им. В.И. Ильичева Дальневосточного отделения Российской академии наук.

Петухов В.И., доктор технических наук, заведующий кафедрой безопасности в чрезвычайных ситуациях и защиты окружающей среды, Дальневосточный федеральный университет. 
UDC 550.42

\title{
HYDROCHEMICAL DISCHARGE OF RIVER WATERS OF SOUTHERN KHABAROVSK REGION IN THE PERIOD OF SUMMER HIGH WATER
}

\author{
Galina Yu. Pavlova ${ }^{1}$ \\ pavlova@poi.dvo.ru
}

\author{
Elena A. Vakh2,1, \\ Adasea@mail.ru
}

Pavel Ya. Tishchenko², tpavel@poi.dvo.ru

\author{
Valeriy I. Petukhov', \\ petukhovv@mail.ru \\ 1 V.I. Ilichev Pacific Oceanological Institute, \\ 43, Baltiyskaya street, Vladivostok, 690041, Russia. \\ 2 Far Eastern Federal University, \\ 8, Sukhanov street, Vladivostok, 690950, Russia.
}

The relevance of the research consists in studying hydrochemical river discharge as one of the main indicators of the ecological state of water objects.

The main aim of the research is to obtain new knowledge on hydrochemical discharge of the rivers at southern Khabarovsk region, which are required for objective assessment of the ecological status of the region and for carrying out effective water protection measures. Objects of the research are the Amur River and seven lesser streams: Bikin, Khor, Podkhorenok, Bira, Kiya, Malaya Chirka, 2-ya Sedmaya. Methods. Concentration of major anions $\left(\mathrm{Cl}_{-}, \mathrm{SO}_{4}^{2-}\right)$ were analyzed by ion chromatography (Shimadzu $\left.\mathrm{LC}-10 \mathrm{~A}\right)$; major cations $\left(\mathrm{Na}^{+}, \mathrm{K}^{+}\right.$, $\mathrm{Ca}^{2+}, \mathrm{Mg}^{2+}$ ), trace elements and rare earth elements - with ICP-MS (Agilent, $7500 \mathrm{c}$ ) method. The hydrocarbonate ion $\left(\mathrm{HCO}_{3}{ }^{-}\right.$) concentration was taken as the total alkalinity. It was analyzed by direct titration by Bruyevich method. The total mineralization $\left(\Sigma_{i}\right)$ is the sum of concentrations of major river water elements.

Results. In July 2011 the Amur River and seven lesser streams (Bikin, Khor, Podkhorenok, Bira, Kiya, Malaya Chirka, 2-aya Sedmaya), located at southern part of Khabarovsk region, were sampled and analyzed for their major elements, trace elements and rare earth elements. During summer flood river waters are low-mineralizated, $\sum i$ does not exceed $50 \mathrm{mg} / \mathrm{l}$. $\mathrm{Ca}^{2+}$ is the predominant cation and $\mathrm{HCO}_{3}{ }^{-}$is the major counter-ion for cations in all samples. High concentrations of dissolved Al, Fe u Pb were found in the surface waters of all the rivers studied. In the Malaya Chirka River there are high concentrations of dissolved $\mathrm{Co}, \mathrm{Cu}, \mathrm{Mn}$ and extremely high $\mathrm{Cd}$, exceeding the average global concentrations in 40 times. The concentration of the other trace elements in the studied rivers is in general corresponded to their average global concentrations and is a characteristic of the natural regional background during summer floods. A regional level of total concentrations of soluble forms of rare earth elements $(1,44-5,44 \mu \mathrm{g} / \mathrm{l})$ was established. The distribution and level of rare earth elements concentrations in the studied river waters reflect the overall composition of the watershed rocks. The calculated total daily fluxes of major elements, trace elements and rare earth elements, supplied by the Bira, Kiya, Podhorenok, Bikin, Khor and Amur rivers, equal to 61894, 377 and 2,21 t/day, respectively.

\section{Key words:}

Hydrochemical discharge, major ions, trace elements, rare earth elements, river, Khabarovsk region.

The research was financially supported by the RFBR grants no. 16-35-60098 мол_а_док., по. 16-05-00166.

\section{REFERENCES}

1. Milliman J.D., Farnsworth K.L. River discharge to the coastal ocean. A global synthesis. Cambridge, Cambridge university press, $2011.384 \mathrm{p}$.

2. Savichev O.G., Mazurov A.K., Pipko I.I., Sergiyenko V.I., Semiletov I.P. Spatial patterns of the evolution of the chemical composition and discharge of river water in the Ob river. Doklady Earth Sciences, 2016, vol. 466, no. 2, pp. 202-206. In Rus.

3. Pipko I.I., Pugach S.P., Semiletov I.P., Anderson L.G., Shakhova N.E., Gustafsson Ö., Repina I.A., Spivak E.A., Charkin A.N., Salyuk A.N., Shcherbakova K.P., Panova E.V., Dudarev O.V. The spatial and interannual dynamics of the surface water carbon ${ }_{a}$ te system and air-sea $\mathrm{CO}_{2}$ fluxes in the outer shelf and slope of the Eurasian Arctic Ocean. Ocean Science, 2017, vol. 13, pp. 997-1016.

4. Drake T.W., Tank S.E., Zhulidov A.V., Holmes R.M., Gurtovaya T., Spencer R.G.-M. Increasing alkalinity export from large Russian Arctic rivers. Environmental Science and Technology, 2018, vol. 52, pp. 8302-8308.
5. Shesterkin V.P., Shesterkina N.M. The influence of large forest fires on the hydrochemical regime of the taiga rivers of the Amur region. Geography and Natural Resources, 2002, no. 2, pp. 47-52. In Rus.

6. Forina Yu.A. Osobennosti khimicheskogo sostava vody malykh rek severnogo Sikhote-Alinya [Features of chemical composition of water of small rivers of the northern Sikhote-Alin]. Chteniya pamyati Vladimira Yakovlevicha Levanidova, 2011, vol. 5, pp. 557-562.

7. Shesterkin V.P., Shesterkina N.M. Transformation of the chemical composition of the Middle Amur waters in the winter low water after transboundary pollution of 2005. Geography and Natural Resources, 2018, no. 1, pp. 52-58. In Rus.

8. Gosudarstvenny doklad o sostoyanii i ob okhrane okruzhayushchey sredy Khabarovskogo kraya $v 2014 \mathrm{~g}$. [State report on the state and environmental protection of the Khabarovsk Territory in 2014]. Ed. by V.M. Shikhalev. Khabarovsk, PRINT Publ., 2015. $219 \mathrm{p}$. 
9. Gosudarstvenny doklad o sostoyanii $i$ ob okhrane okruzhayushchey sredy Khabarovskogo kraya $v 2016 \mathrm{~g}$. [State report on the state and environmental protection of the Khabarovsk Territory in 2016]. Ed. by A.B. Ermolin. Izhevsk, PRIN-2 Publ., 2017. 226 p.

10. Sostoyanie morskikh ekosistem, nakhodyashchikhsya pod vliyaniem stoka reki Amur [The state of marine ecosystems under the influence of the flow of the Amur River]. Ed. by V.P. Chelomin. Vladivostok, Dalnauka Publ., 2009. 238 p.

11. Chudayeva V.A. Migratsiya khimicheskikh elementov v vodakh Dalnego Vostoka [Migration of chemical elements in the waters of the Far East]. Vladivostok, Dalnauka Publ., 2002. 392 p.

12. Pavlova G.Yu., Tishchenko P.Ya., Volkova T.I., Dickson A., Wallmann K. Intercalibration of the Bruevich method for determining the total alkalinity in seawater. Oceanology, 2008, vol. 48, no. 3, pp. 477-483. In Rus.

13. Mnogoletnie dannye o rezhime i resursakh poverkhnostnykh vod sushi [Long-term data on the regime and resources of surface land waters]. Ed. by T.S. Shmidt. Leningrad, Gidrometeoizdat Publ., 1986. Vol. 1, no. 21, 387 p.

14. Avtomatizirovannaya informatsionnaya sistema gosudarstvennogo monitoringa vodnykh obyektov [Automated information system for state monitoring of water objects]. Available at: https://gmvo.skniivh.ru/ (accessed 12 January 2019).

15. Alekin O.A. Osnovy gidrokhimii [Basics of hydrochemistry] Leningrad, Gidrometizdat Publ., 1970. 444 p.

16. Vakh E.A., Pavlova G.Yu., Mikhaylik T.A., Tishchenko P.Ya., Semkin P.Yu. Basic salt composition and rare earth elements as indicators of ecological state of the river of southern Primorye. Bulletin of the Tomsk Polytechnic University. Geo Assets Engineering, 2017, vol. 328, no. 1, pp. 39-49. In Rus.

17. Meybeck M. Global occurrence of major elements in rivers. Surface and ground water, weathering and soils. Treatise of Geochemistry. Eds. H.D. Holland, K.K. Turekian. Amsterdam, Elsevier, 2004. Vol. 5, pp. 207-223.
18. Bersenev Yu.I. Karst Dalnego Vostoka [Far East Karst]. Moscow, Nauka Publ., 1989. 172 p.

19. Cai W.J., Guo, X., Chen C.T.A. A comparative overview of weathering intensity and $\mathrm{HCO}_{3}$ flux in the world's major rivers with emphasis on the Changjiang, Huanghe, Zhujiang (Pearl) and Mississippi Rivers. Continental Shelf Research, 2008, vol. 28, pp. $1538-1549$.

20. Gaillardet J., Dupre B., Laouvat P., Allegre C.J. Global silicate weathering and $\mathrm{CO}_{2}$ consumption rates deduced from the chemistry of large rivers. Chemical Geology, 1999, vol. 159, pp. 3-30.

21. Tishchenko P.Ya., Mikhaylik T.A., Pavlova G.Yu., Tishchenko P.P., Koltunov A.M., Jing Zhang. Carbonate equilibrium of the waters of the Razdolnaya River. Geochemistry, 2017, vol. 55, no. 3, pp. 236-248. In Rus.

22. White A.F., Blum A.E. Effect of climate on chemical weathering in watersheds. Geochimica et cosmochimica acta, 1995, vol. 59, pp. 1729-1747.

23. Gordeyev V.V. Geokhimiya sistemy reka-more [Geochemistry of sea-river system]. Moscow, IP Matushkina I.I. Publ., 2012. 452 p.

24. Gaillardet J., Viers J., Dupre B. Trace elements in rivers waters. Treasure on Geochemistry. Amsterdam, Elsevier Pergamon, 2004. Vol. 5, pp. 225-272.

25. Elbaz-Poulichet F., Braungardt Ch., Achterberg E. Metal biogeochemistry in the Tinto-Odiel rivers (Southern Spain) and in the Dulf of Cadiz: a synthesis of the results of TOROS project. Continental Shelf Research, 2001, vol. 21, pp. 1961-1973.

26. Balashov Yu.A. Geokhimiva redkozemelnykh elementov [Geochemistry of rare earth elements]. Moscow, Nauka Publ., 1976. $267 \mathrm{p}$.

27. Gromet L.P., Dumek R.F., Haskin L.A., Korotev R.L. The «North American shale composite»: its composition, major and trace element characteristics. Geochimica et Cosmochimica Acta, 1984, vol. 48, pp. 2469-2482.

Received: 14 January 2019.

\section{Information about the authors}

Galina Yu. Pavlova, Cand. Sc., leading researcher, V.I. Ilichev Pacific Oceanological Institute.

Elena A. Vakh, Cand. Sc., researcher, Far Eastern Federal University; V.I. Ilichev Pacific Oceanological Institute.

Pavel Ya. Tishchenko, Dr. Sc., head of laboratory, V.I. Ilichev Pacific Oceanological Institute.

Valeriy I. Petukhov, Dr. Sc., professor, Far Eastern Federal University. 